\title{
Formation of a Vasopressor Substance in the Incubated Serum of Patients with Various Hypertensive Diseases
}

\author{
Masaru Maebashi and Kaoru Yoshinaga \\ The Second Department of Internal Medicine, Tohoku \\ University School of Medicine, Sendai 980
}

\begin{abstract}
Maebashi, M. and Yoshinaga, K. Formation of a Vasopressor Substance in the Incubated Serum in Patients with Various Hypertensive Diseases. Tohoku J. exp. Med., 1984, 142 (2), 173-182 — A vasoactive substance was produced in serum when incubated at $37^{\circ} \mathrm{C}$. This substance differed from other known vasoactive agents. It was a phospholipid and caused an elevation in blood pressure by its direct vasoconstriction. This pressor substance increased in the incubated sera of patients with essential hypertension and in spontaneously hypertensive rats. But it was significantly low in humans and dogs in anephric states. These results suggest that the pressor substance participates in the pressor mechanism of essential hypertension and its production is closely related to the kidney. —— vasoactive substance; hypertension; phospholipid ; incubated serum
\end{abstract}

Since Goldblatt's discovery (Goldblatt et al. 1934) of renin in the ischemic kidney, many attempts have been directed to pressor agents responsible for an elevation in blood pressure. Among these agents, angiotensin II and catecholamine have been well known as potent pressor substances. These substances, however, are involved in the main pressor mechanisms only in renovascular hypertension and pheochromocytoma, respectively. In essential hypertension these substances have been presumed not to be directly related to the development and maintenance of high blood pressure, because these substances in serum are nearly within or slightly above normal ranges in such patients. Several groups of workers (Arneil and Dekanski 1954; Masson et al. 1957; Khairallah and Page 1960; Kenner and Waldhäusl 1964; Gordon and Rieske 1967; Roblero and Croxatto 1968; Skeggs et al. 1977; Tokumura et al. 1978) have reported the presence of hitherto unknown vasoactive substances in mammalian tissues and plasma, but the chemical and pharmacological properties of these substances are still controversial.

The present study was performed with sera obtained from patients with various hypertensive diseases and from experimental animals. The pressor substance was increased in the incubated sera of patients with essential hypertension and of spontaneously hypertensive rats (SHR). Furthermore, the role of the

Received for publication, May 11, 1983. 
kidney in the production of this substance was investigated in nephrectomized dogs.

\section{Materials and Methods}

\section{Bioassay of the pressor substance}

Male Wistar rats, weighing 250-300 g, were anesthetized with intraperitoneal injection of sodium pentobarbital $(50 \mathrm{mg} / \mathrm{kg}$ ) and ganglion-blocked with hexamethonium bromide $(2.5 \mathrm{mg} / \mathrm{rat})$. The carotid artery and the femoral vein were cannulated for blood pressure measurement and sample injection, respectively. The blood pressure was recorded by an ink-writing recorder (Nihon Kohden, Type RM-25) connected to a pressure transducer (Nihon Kohden, Type MP-4S). Human serum obtained from fasting venous blood was incubated at $37^{\circ} \mathrm{C}$ for $48 \mathrm{hr}$ and injected intravenously into the test rats. The pressor activity in the incubated serum was determined by comparing with that of the standard solution of synthetic angiotensin II and its level was expressed in terms of angiotensin II. Statistical analysis was performed by Student's $t$-test.

\section{Purification of the pressor substance}

The extraction of the pressor substance was tried according to the method of Folch et al. (1956). To the incubated serum, 10 volumes of a mixture of chloroform-methanol (2 : $1 \mathrm{v} / \mathrm{v}$ ) were added. After filtration, the organic phase was evaporated to dryness under reduced pressure at $40^{\circ} \mathrm{C}$ and the residue was chromatographed on a column of silicic acid (Wakogel C-200, Wako Pure Chemical), and eluted successively with dichloromethane, acetone, dichloromethane-methanol $(65: 35 \mathrm{v} / \mathrm{v})$ and methanol-water $(95: 5 \mathrm{v} / \mathrm{v})$ according to the method of Nelson and Freeman (1959). The latter two methanol eluates were combined, applied to thin layer plates coated with silicic acid (Wakogel B-5, Wako Pure Chemical) and developed with chloroform-methanol-acetic acid-water (50:25:8:4 v/v) following the method of Skipski et al. (1964). N-Butanol-acetic acid-water (60:20:20 v/ v) was used as the second solvent when two dimensional development was required. The plates were scraped off and eluted with chloroform-methanol $(1: 1 \mathrm{v} / \mathrm{v})$ mixture. Each of the eluates was evaporated to dryness and bioassayed. Phosphatidylcholine, phosphatidylethanolamine, sphingomyelin, lysophosphatidylcholine, lysophosphatidylethanolamine, phosphatidic acid and prostaglandin $\mathrm{F}_{2 \alpha}$ (Sigma) were used as reference agents.

\section{REsults}

Intravenous injection of serum incubated at $37^{\circ} \mathrm{C}$ into the rat caused a rapid and transient elevation in blood pressure, while non-incubated serum had not any pressor activity (Fig. 1). The pattern and time course of the pressor response to the incubated serum resembled those to angiotensin II and norepinephrine. The pressor response was proportionate to the dose of the injected serum. The level of the pressor substance produced in the serum was progressively increased with incubation time. The pressor activity appeared at $3 \mathrm{hr}$-incubation, reached a maximum at $24 \mathrm{hr}$ and maintained the plateau up to $72 \mathrm{hr}$ (Fig. 2). Further incubation showed a gradual reduction of the pressor activity. Thus, the present study was performed with serum incubated at $37^{\circ} \mathrm{C}$ for $48 \mathrm{hr}$.

\section{Physical properties}

The pressor substance produced in the incubated serum was neither dialyz- 


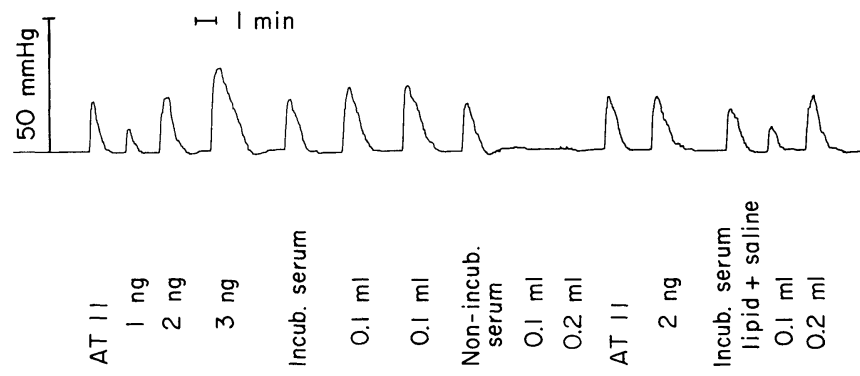

Fig. 1. Pressor activity in the incubated human serum. AT II, angiotensin II ; Incub. serum, incubated serum; Non-incub. serum, non-incubated serum; Incub. serum lipid Folch's extract from the incubated serum.

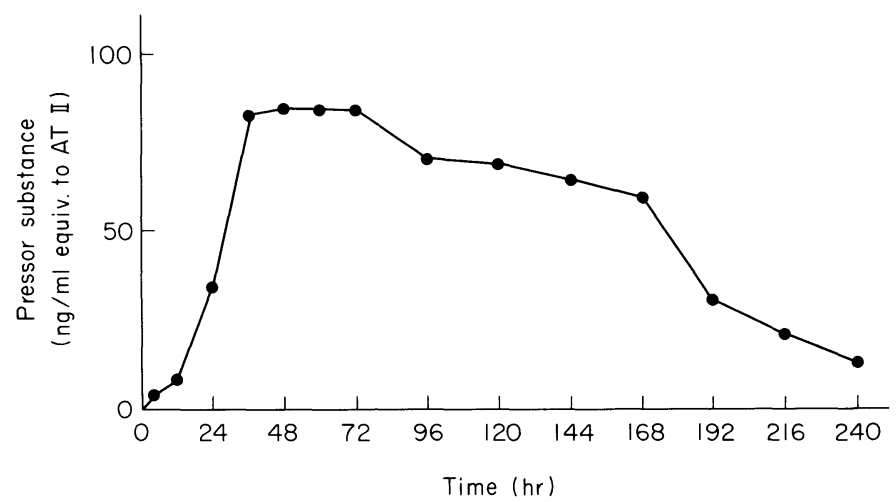

Fig. 2. Effect of incubation time on the production of a pressor substance in human serum.

able against running tap water nor destroyed by boiling for 5 min. Incubation of the serum with trypsin ( $\mathrm{pH} 7.4)$ or chymotrypsin $(\mathrm{pH} 7.4)$ did not affect the pressor activity. Dialyzed serum did not yield any pressor activity on incubation, but the addition of $\mathrm{CaCl}_{2}, 10 \mathrm{mg} / 100 \mathrm{ml}$, to the dialyzed serum restored full activity when incubated as usual. Incubation of serum at various $\mathrm{pHs}$, ranging from 4.0 to 10.0 , showed the maximal activity at 7.4 (Fig. 3).

\section{Chemical properties}

Extraction procedures in the determinations of plasma angiotensin II (Maebashi 1964) and catecholamine (Renzini et al. 1970) did not extract the pressor substance from the incubated serum. The pressor substance was extracted with Folch's solvent and separated by silicic acid column chromatography. The pressor substance was recovered in the methanol fractions in which phospholipids were eluted out. On thin layer chromatography the phospholipids were separated into four spots. The pressor activity was detected in a spot with Rf value of 


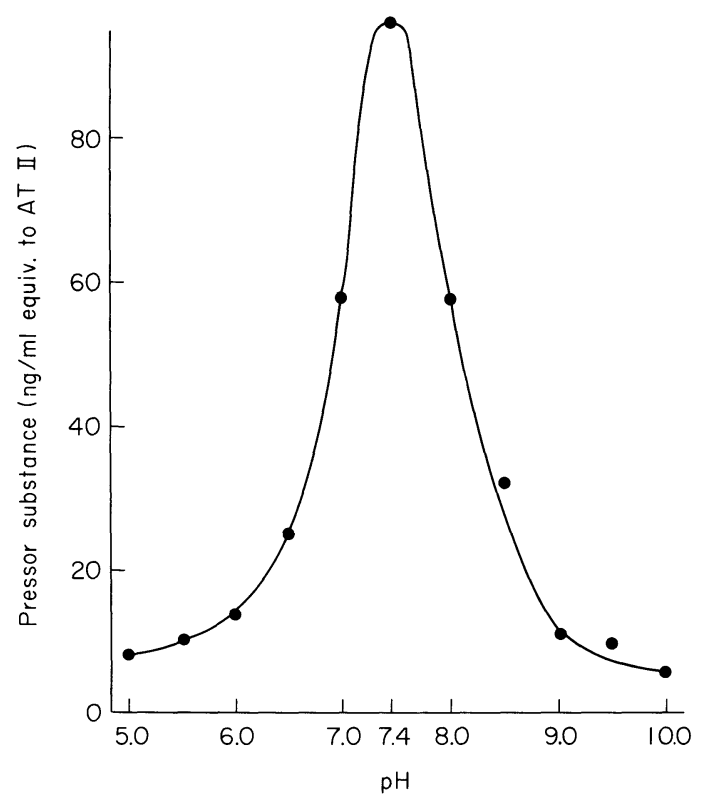

Fig. 3. Production of a pressor substance at various pHs.

lysophosphatidylcholine (Fig. 4). This spot was developed dark blue by ammonium molybdate-perchloric acid reagent for phospholipids and yellow by Dragendorff reagent for choline. It was colorless to ninhydrin reagent for amino group. Thus, this substance was proved to be a phospholipid having choline without amino group

\section{Characterization of the pressor substance}

To examine the pressor mechanism of the incubated serum, the rats were treated with various drugs prior to the experiments. As shown in Table 1, pretreatment with phenoxybenzamine, propranolol or reserpine had no effect on the pressor activity. Similarly, the rats pretreated with methysergide, captopril or indomethacin responded to the incubated serum with full activity when compared with the sham treated rats with saline solution. Diltiazem, a $\mathrm{Ca}^{2+}$ channel blocker, suppressed the pressor activity at the doses ranging from $0.1 \mathrm{mg} /$ $\mathrm{kg}$ to $1 \mathrm{mg} / \mathrm{kg}$.

\section{Contractile activity of the rat aortic strip}

The contractile activity of the incubated serum on vascular smooth muscle was examined in isolated rat aortic strips. Spirally cut thoracic aortic strips (approx. $1 \mathrm{~mm}$ wide and $15 \mathrm{~mm}$ long) was suspended in an organ bath with $15 \mathrm{ml}$ of modified Locke solution. A tension of $0.5 \mathrm{~g}$ was initially applied to the strips and isometric contraction was recorded on an ink-writing recorder (Nihon 


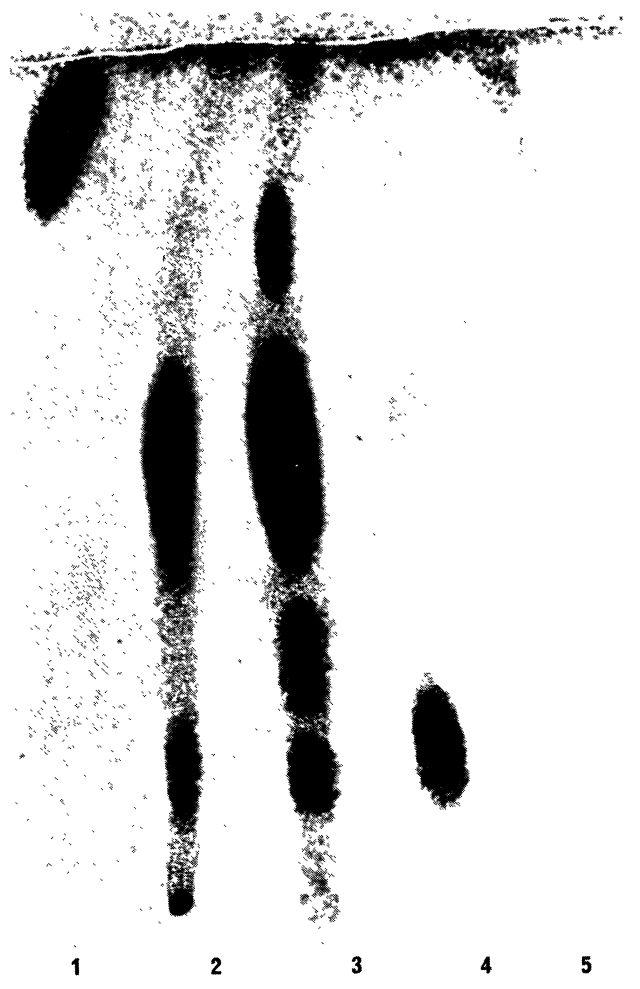

Fig. 4. Thin layer chromatogram of phospholipids isolated from the incubated human serum. The plate was visualized with ammonium molybdate-perchloric acid reagent. 1, prostaglandin $F_{2 \alpha} ; 2$, phosphatidylcholine and lysophosphatidylcholine ; 3 , isolated phospholipid (from solvent front to bottom spot represents in order phosphatidylethanolamine, phosphatidylcholine, sphingomyelin and lysophosphatidylcholine); 4, lysophosphatidylcholine ; 5, phosphatidic acid.

TABLE 1. Inhibitory effects of various drugs on the pressor activity of the incubated serum

\begin{tabular}{lccccc}
\hline \multicolumn{1}{c}{ Drug } & \multicolumn{4}{c}{ Dose } & Effect \\
\hline Phenoxybenzamine & 1 & -3 & $\mathrm{mg} / \mathrm{kg}$ & $\mathrm{i} . \mathrm{v}$. & - \\
Propranolol & $0.1-0.3$ & " & " & - \\
Reserpine & 1 & -3 & $\prime \prime$ & " & - \\
Hexamethonium & 1 & -3 & " & " & - \\
Clonidine & 20 & $\mu \mathrm{g} / \mathrm{kg}$ & " & - \\
Methysergide & $0.5-1$ & $\mathrm{mg} / \mathrm{kg}$ & " & - \\
Captopril & $0.5-1$ & $\prime \prime$ & " & - \\
Indomethacin & 3 & -5 & $\prime \prime$ & " & - \\
Diltiazem & $0.1-1$ & " & " & + \\
\hline
\end{tabular}

Kohden, Type RM-25) through a strain gauge transducer (Shiko Communication, Type UL-10-240). After the resting tension had been stabilized, norepinephrine and the incubated serum were administered. Experiments were carried out at $37^{\circ}$ C. As shown in Fig. 5, the tension of the aortic strip was elicited by the addition of the incubated serum into the bath. Diltiazem suppressed its tension at the concentration of $10^{-6} \mathrm{M}$. 

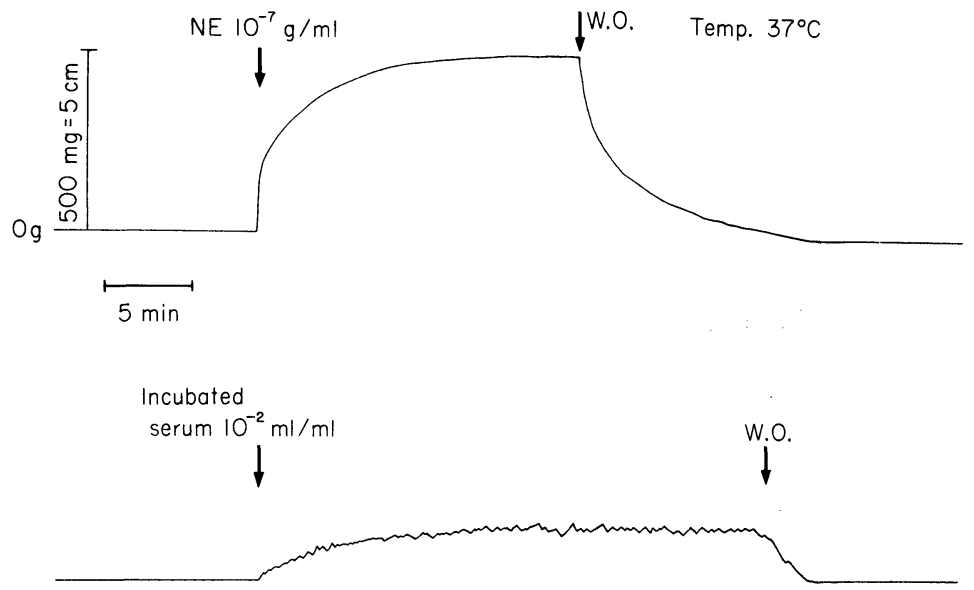

Fig. 5. Contractile response of isolated aortic strip of rat to the incubated human serum. NE, norepinephrine; W.O., washout with saline solution.

\section{Effect of nephrectomy on the production of the pressor substance}

Five mongrel dogs, both sexes weighing $15-20 \mathrm{~kg}$, were used. They were nephrectomized bilaterally under sodium pentobarbital anesthesia $(25 \mathrm{mg} / \mathrm{kg}$, intravenously). Blood samples were drawn from the jugular vein at $24 \mathrm{hr}$ intervals, before and after nephrectomy for successive 3 days. The results are summarized in Table 2 . The pressor substance decreased progressively after nephrectomy, suggesting that the kidney was closely related to the production of the pressor substance.

Pressor substance in spontaneously hypertensive rats

Male spontaneously hypertensive rats (SHR) at the ages of 9 and 30 weeks were used in this study. Male normotensive Wistar rats at 10 weeks of age were served as controls. The rats were fed on a standard food (Nihon Clear Chow) and water ad libitum. Preoperative systolic blood pressure was measured in unanesthetized rats using the tail cuff method. Blood samples were collected from the abdominal aorta under ether anesthesia. As shown in Table 3, the pressor substance in the incubated serum was significantly higher in the hypertensive rats than that in the control rats and correlated with increasing level of blood pressure of SHR.

TABLE 2. Effect of bilateral nephrectomy on the production of a pressor substance in the incubated serum of 5 dogs

\begin{tabular}{cccc}
\hline Before & $24 \mathrm{hr}$ after & $48 \mathrm{hr}$ after & $72 \mathrm{hr}$ after \\
\hline $35.9 \pm 4.8$ & $25.1 \pm 5.8$ & $15.0 \pm 4.0$ & $11.6 \pm 2.0$
\end{tabular}

Unit: ng equivalent to $\mathrm{AT} \mathrm{II/ml}$.

Mean \pm s.E. 


\section{Pressor substance in hypertensive patients}

The pressor substance in the incubated serum was estimated in 249 in patients with various hypertensive diseases and in 66 healthy normotensive subjects, ranging in age from 20 to 70 years. Patients who had been treated with hypotensive drugs, hypolipidemic drugs or steroids were excluded from the study. Blood samples were taken in the morning after overnight fast. Incubated sera were bioassayed. Simultaneously plasma renin activity was measured in the same patients and subjects by the bioassay method described previously (Maebashi 1964). The results are summarized in Table 4. The pressor substance was significantly elevated in patients with essential hypertension and malignant hyperten-

TABLE 3. Levels of a pressor substance in the incubated serum of spontaneously hypertensive rats (SHR) and control Wistar rats

\begin{tabular}{lccc}
\hline & Control & \multicolumn{2}{c}{ SHR } \\
\hline Age (weeks) & $10(N=5)$ & $9(N=5)$ & $30(N=5)$ \\
Body weight (g) & $230 \pm 20$ & $130 \pm 20$ & $300 \pm 20$ \\
$\begin{array}{l}\text { Systolic blood } \\
\text { pressure (mmHg) }\end{array}$ & $110-130$ & $160-170$ & $190-210$ \\
$\begin{array}{c}\text { Pressure substance } \\
\quad \text { (ng equiv. to AT II/ml) }\end{array}$ & $48.6 \pm 8.8$ & $68.8 \pm 8.2$ & $125.2 \pm 4.5$ \\
\hline
\end{tabular}

Mean \pm S.E.

TABLE 4. Levels of a pressor substance in the incubated serum and plasma renin activity in patients with various hypertensive diseases

\begin{tabular}{lccc}
\hline & $\begin{array}{c}\text { Number } \\
\text { of cases }\end{array}$ & $\begin{array}{c}\text { Pressor sub- } \\
\text { stance }(\mathrm{ng} / \mathrm{ml})\end{array}$ & $\begin{array}{c}\text { Plasma renin } \\
\text { activity }(\mathrm{ng} / \mathrm{ml})\end{array}$ \\
\hline Normal & 66 & $41.9 \pm 1.5$ & $1.1 \pm 0.1$ \\
Essential hypertension & 76 & $71.4 \pm 4.5^{*}$ & $1.1 \pm 0.1$ \\
Malignant hypertension & 13 & $50.4 \pm 4.5$ & $6.8 \pm 1.1^{*}$ \\
Renovascular hypertension & 18 & $34.0 \pm 2.8 \dagger$ & $4.2 \pm 0.8^{*}$ \\
Chronic glomerulonephritis & 22 & $39.8 \pm 2.2$ & $1.2 \pm 0.1$ \\
Chronic pyelonephritis & 16 & $38.0 \pm 5.2 \ddagger$ & $1.7 \pm 0.3$ \\
Chronic renal failure & 25 & $28.9 \pm 3.1$ & $0.9 \pm 0.1$ \\
Primary aldosteronism & 23 & $42.6 \pm 2.9$ & $0.9 \pm 0.1$ \\
Cushing syndrome & 13 & $43.3 \pm 5.2$ & $0.9 \pm 0.1$ \\
Pheochromocytoma & 13 & $46.9 \pm 5.8$ & $4.4 \pm 0.8^{*}$ \\
Diabetes mellitus & 20 & $43.7 \pm 3.2$ & $1.0 \pm 0.1$ \\
Coarctation of the aorta & 7 & $38.6 \pm 1.9$ & $0.8 \pm 0.1$ \\
17 $\alpha$-hydroxylase deficiency & 2 & $42.7,55.3$ & $0.5,0.3$ \\
Renin secreting tumor & 1 & 56.7 & 19.4 \\
\hline
\end{tabular}

Mean \pm s.E.

Significantly different from the corresponding normal value:

${ }^{*} p<0.001, \dagger p<0.005, \ddagger p<0.05$. 
sion as compared with that in the control subjects. On the contrary, the pressor substance was significantly low in patients with chronic renal failure. In hypertensive patients, in whom other pressor agents such as renin-angiotensin or catecholamine were elevated, the pressor substance was nearly within or slightly above normal ranges. There was no correlation between the pressor substance and plasma renin activity. Other forms of hypertension showed normal level of the pressor substance.

\section{Discussion}

The present study confirmed the production of a pressor substance when sera of humans, dogs and rats were incubated at $37^{\circ} \mathrm{C}$ for $48 \mathrm{hr}$. However, denaturation of serum by boiling prior to incubation did not produce any pressor substance. Dialyzed serum did not yield a pressor substance, either, while the addition of $\mathrm{Ca}^{2+}$ to the dialyzed serum restored the production. This fact suggests that an unidentified substance, presumably an enzyme, in the serum may act on some substrate to produce a pressor substance. The pressor substance was non-dialyzable and resistant to proteolytic enzymes. The substance retained its full pressor activity even after boiling. The pressor substance could not be extracted by the extraction procedures in the determinations of angiotensin II (Maebashi 1964) and catecholamine (Renzini et al. 1970). The production of the pressor substance was not affected, even if serum was hemolyzed, while the two agents could not be detected in hemolyzed serum when incubated at $37^{\circ} \mathrm{C}$. There was no correlation between the pressor substance and plasma renin activity or catecholamine in patients with renovascular hypertension or pheochromocytoma. From these results, it is concluded that the pressor substance in the incubated serum differs from angiotensin II and catecholamine.

The pressor substance was proved to be a phospholipid on the basis of chemical properties, such as solubility in Folch's solvent and chromatographic behaviors. On thin layer chromatography the pressor substance isolated from the incubated serum gave a spot with $\mathrm{Rf}$ value identical to lysophosphatidylcholine, the $\mathrm{Rf}$ being different from those of prostaglandin, phosphatidic acid and its derivatives. Thus the present substance is different from vasopressor substance found in soybean by Tokumura et al. (1978). Kenner and Waldhäusl (1964) and Roblero and Croxatto (1968) showed the existence of a vasoactive substance in sera of rats and dogs. This substance, however, could be easily distinguished from the present substance, because their substance was a protein. The present substance is similar in chemical properties to the substance described by Khairallah and Page (1960). But unlike their report, phospholipids from egg yolk and soybean produced sustained hypertension when injected intravenously into rats (to be published).

The pressor substance was elevated in the incubated serum of patients with essential hypertension. Similarly, this substance was increased in spontaneously 
hypertensive rats. In contrast, the pressor substance was significantly low in patients with chronic renal failure and in nephrectomized dogs. Thus it seems likely that the pressor substance is, in part at least, involved in the pressor mechanism of essential hypertension and that its production is closely related to the kidney. As described previously, the pressor substance differs in its pressor and vasoconstrictor actions as well as in its chemical properties from angiotensin II, catecholamine and serotonin. Unlike these agents, the pressor activity of the incubated serum was not blocked by pharmacological adrenosympathectomy with adrenergic receptors blockers or reserpine or by serotonin antagonist. Together with these findings, lack of the effect or captopril or indomethacin indicates that the action of the incubated serum is not mediated through these classical receptors or other known principles such as the renin-angiotensin system or the products of the cyclooxygenase pathway. Furthermore, the fact that the incubated serum caused a contraction of isolated rat aorta indicates that the pressor effect is due to a direct vasoconstriction. More detailed studies on chemical properties and pathophysiological significance of this pressor substance, especially on the relation to essential hypertension, is now in progress.

\section{References}

1) Arneil, G.C. \& Dekanski, J.B. (1954) Excess of vasopressor activity in plasma of nephritic children with hypertension. Lancet, 2, 1204-1207.

2) Folch, J., Lees, M. \& Samley, G.H.S. (1956) A simple method for the isolation and purificaton of total lipids from animal tissues. J. biol. Chem., 226, 497-509.

3) Goldblatt, H., Lynch, J., Hanzal, R.F. \& Summerville, W.W. (1934) Studies on experimental hypertension. I. The production of persistent elevation of systolic blood pressure by means of renal ischemia. J. exp. Med., 59, 347-379.

4) Gordon, D.B. \& Rieske, C.L. (1967) Arneil factor: A pressor substance, probably a protein, in incubated plasma. Fed. Proc., 26, 378.

5) Kenner, Th. \& Waldhäusl, W. (1964) A non-dialysable, heat-stable, hypertensive substance in the serum of rats. Nature, 204, 581-582.

6) Khairallah, P.A. \& Page, I.H. (1960) A vasopressor lipid in incubated plasma. Amer. J. Physiol., 199, 341-345.

7) Maebashi, M. (1964) Estimation of circulating renin under various clinical conditions. Jpn. Circulat. J., 28, 778-785.

8) Masson, G.M.C., Helmcke, G., Corcoran, A.C. \& Page, I.H. (1957) Pressor and myotrophic activities of incubated plasma. Proc. Soc. exp. Biol. Med., 94, 544-546.

9) Nelson, G.J. \& Freeman, N.K. (1959) Serum phospholipide analysis by chromatography and infrared spectrophotometry. J. biol. Chem., 234, 1375-1380.

10) Renzini, V., Brunori, C.A. \& Valori, C. (1970) A sensitive and specific fluorimetric method for the determination of noradrenaline and adrenaline in human plasma. Clin. chim. Acta, 30, 587-594.

11) Roblero, J. \& Croxatto, H. (1968) Vasoactive substance formed in blood serum by incubation. N.Y. St. J. Med., 68, 235-242.

12) Skeggs, L.T., Kahn, J.R., Levine, M., Dorer, F.E. \& Lentz, K.E. (1977) Chronic onekidney hypertension in rabbits. III. Renopressin, a new hypertensive substance. Circulat. Res., 40, 143-149.

13) Skipski, V.P., Peterson, R.J. \& Barclay, M. (1964) Quantitative analysis of phos- 
pholipids by thin layer chromatography. Biochem. J., 90, 374-378.

14) Tokumura, A., Fukuzawa, K., Akamatsu, Y., Yamada, S., Suzuki, T. \& Tsukatani, H. (1978) Identification of vasopressor phospholipid in crude soybean lecithin. Lipids, 13, $468-472$. 